\title{
REVIEW OF PROBLEMS IN THE DEVELOPMENT OF RAIL TOURISM IN TAIWAN, ON THE EXAMPLE OF THE ALISHAN FOREST RAILWAY
}

\author{
Ka Leong CHONG* \\ Sunway University, School of Hospitality, 5 Jalan University, Bandar Sunway, \\ 4750o Selangor, Malaysia, e-mail: danielc@sunway.edu.my
}

\begin{abstract}
Citation: Chong, K.L. (2019). REVIEW OF PROBLEMS IN THE DEVELOPMENT OF RAIL TOURISM IN TAIWAN, ON THE EXAMPLE OF THE ALISHAN FOREST RAILWAY. GeoJournal of Tourism and Geosites, 26(3), 943-955. https://doi.org/10.30892/gtg.26321-409
\end{abstract}

\begin{abstract}
Rail tourism is significant in boosting Taiwan's tourism industry with more than 560,000 tourists visited Alishan railway, one of the most significant heritage rail tourism sites in 2018. However, recently more attentions and efforts were being put on High-Speed-Rail instead of heritage rails in Taiwan. As the Taiwan Railways Administration launched the 10 years plan in replacing the heritage rail, it has raised the question of sustainability of the heritage rail tourism in Taiwan. The study aims to assess the challenges faced in developing heritage rail tourism in Taiwan by using the Porter's Diamond Model as the assessment criteria. The data was collected through a variety of methods inclusive of interviews, observations, and review of challenges faced in the process of preparing the existing heritage railways for the future of Taiwan's rail tourism. This study found that despite the popularity, financial subsidies and extensive promotion effort by Taiwan Railways Administration, the heritage rail tourism in Taiwan is still facing difficulties in remaining sustainable in the long-run due to inefficient firm strategy, poor pricing strategy, and also non-user-friendly online ticketing system.
\end{abstract}

Key words: Tourism Policy, Rail Tourism, Porter's Diamond Model, Alishan Forest Railway

\section{INTRODUCTION}

Rail Tourism is commonly referred to any tourism and leisure trips that use railways to transport tourists (Jensen, 1999). The initial form of rail tourism can be traced back to 1870s where travellers sought beautiful mountainous or coastal landscapes as part of entertainment and discovery. A second form of rail tourism happened after 1950s that was related to heritage and based on enthusiasts' nostalgia for old trains developed. Eventually, a hybrid forms of rail tourism that combine discovery and heritage have emerged after 1980s. Consequently, rail tourism has increasingly been developed by combining the pleasures of discovery, comfortable travel and nostalgic searching (Pine \& Gilmore, 1998).

\footnotetext{
* Corresponding author
} 
On a specific branch of rail tourism - Heritage Rail Tourism refers to vacation that involve transportation that is conducted by heritage railway (Tillman, 2002). It is especially popular in Europe and India where the railway networks are well developed and promoted. Its popularity has caught the attention of emerging tourism operators like Japan and Taiwan in the early 1990s. However, it was only the recent years that railway tourism in Taiwan is gradually gaining back its popularity. The history of rail tourism in Taiwan dates back to 1992, when President of Republic of China, Mr. Lee Teng Hui who took the round-island train trip after the round-island network is completed gave instructions to TRA (Taiwan Railways Admiration) to promote railway tourism in Taiwan (Hwang, 2010). Tourism is one of the major industry in Taiwan. According to reports by Taiwan Tourism Bureau (2015), the number of visitors travelling to Taiwan showed positive growth every year with approximately $72 \%$ of the total number of visitors visited Taiwan for recreational purposes. In 2018, out of 2,221,431 visitors, more than 560,000 tourists visited Alishan railway, which is one of the most popular tourist attractions in Taiwan (Ceicdata, 2018). The statistic shows that rail tourism is still significant in boosting Taiwan's tourism industry generating revenue of approximately USD $\$ 732$ million in 2018 solely on ticket sales (Taipeitimes, 2019).

Taiwan railway acts as one of the links for tourists to travel to places and brings tourists to different attractions in Taiwan. Thus, Taiwan government puts a lot of effort in promoting rail tourism in Taiwan. Yet, most of the promotions made by the government are more towards the Taiwan High-Speed Rail (HSR) than the Taiwan heritage railway. Currently, there are only 4 branch lines that use traditional trains in Taiwan, with some of the lines being one of the most popular tourist attractions (Tourism Bureau, 2015). However, more attention and effort are being put on HSR instead of heritage rails in Taiwan, as more High-Speed Rail (HSR) stations are being built, with a total of 12 stations as of today (Wang \& Lee, 2016). The increase of High-Speed Rail (HSR) stations have raised the question of whether heritage rail would be able to sustain in the future.

Based on recent studies by Shelley (2015), the sustainability of the heritage railway is questionable, whereby it is essential to incur high cost in maintaining the heritage railways in Taiwan. As such, the cost refers to track maintenance cost, labor cost, and operation cost. For example, it could cost as high as USD \$573 million to maintain and renew the tracks that reached fatigue and replacement level, as the tracks disintegrate through time (Taiwan Railways Administration, 2016). As a result, this has led to a great challenge to the TRA. Furthermore, the heritage rail is facing sustainability issue due to strong competition. Direct competition causes heritage rail to be viewed as low speed, time consuming, and low accessibility. One of the direct competitors of heritage rail is Taiwan's high-speed rail (HSR). HSR was introduced in 2007, and it mainly depends on imported technology as well as hardware from Japan's Shinkansen line.

Additionally, HSR was supported with the European (High-Speed Train and Intercity-Express) traffic management system (Andersson, et al., 2012). With all the advantages, High-Speed Rail (HSR) is able to shorten the travel time compared to the heritage rail. In addition, the HSR route was planned to prevent the occurrence of earthquake and soft grounds in order to ensure safety for passengers (Andersson et al., 2010). Hence, the high accessibility, safety, and convenience brought by High-Speed Rail (HSR) is strongly capable in lowering the demand for heritage rail.

According to the news from the Taipei Times, TRA aimed to replace the heritage rail by purchasing 1,307 new trains within the upcoming 10 years (Shelley, 2015). As the TRA launched the 10 years plan in replacing the heritage rail, it has proven that there is an issue on the sustainability of the heritage rail tourism in Taiwan. Thus, the objectives of this research are to explore the challenges faced throughout the development process of realizing heritage rail tourism in Taiwan through reviewing the current policies, 
regulations, and strategies practiced by both government and non-government bodies which have direct and indirect relationship with the railway operations.

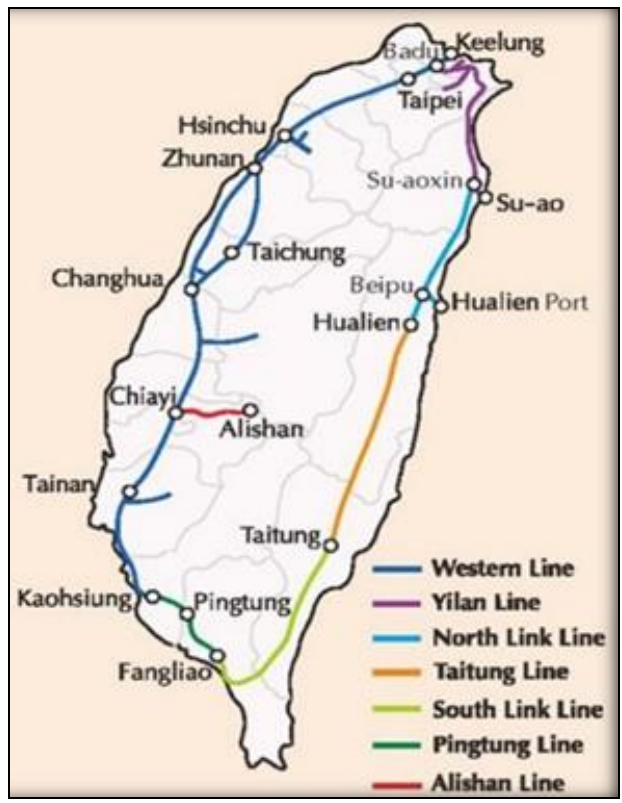

Figure 1. Taiwan Railway System

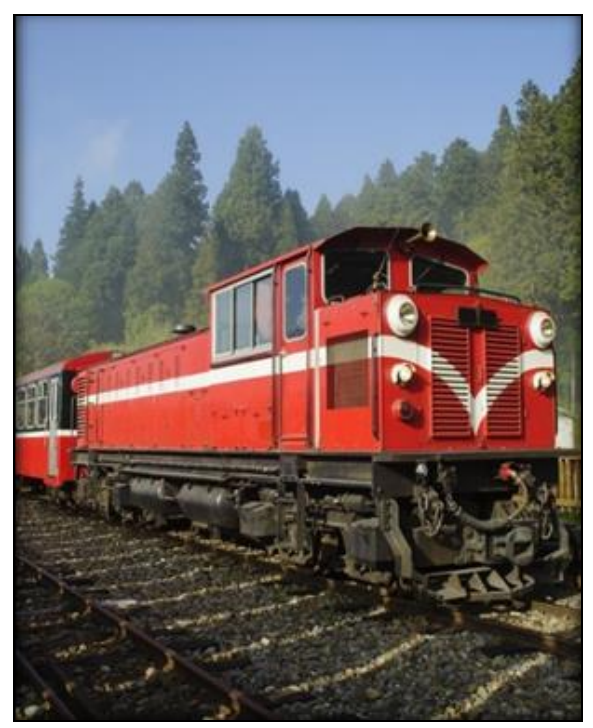

Figure 2. Alishan Heritage Rail

\section{LITERATURE REVIEW}

Past studies on rail tourism related to market behavior were found to be the most researched area. These researches (e.g. Holley \& Jain, 2007; Lyons et al., 2008; Watts, 2008; Cheng, 2010; Lyons et al., 2010; Kolosinska et al., 2018) have examined customers' behavior and their appreciation towards rail tourism. These studies aimed to understand customer's needs, the appreciation of travelling time for different type of passengers and the factors that influence passenger's choice of travelling mode. Findings have shown the factors like anxiety, travel time, service provided and purpose of travelling are the main determinant that drives the intention to travel with rail. Besides that, research on the potential of rail tourism was carried by Jain and Lyons (2008) in the United Kingdom and Brons et al. (2009) in the Netherlands. Both researches focused on future potential of rail tourism and aim to introduce new concepts that could increase the appreciation of travelling with rail. Their findings revealed that positive perception and experience could improve satisfaction. Other than that, future investment, marketing, refurbishment and railway accessibility would potentially increase the use of railway.

On the other hand, the impact of rail tourism has also caught the attention of Chan et al., and Chan (2002) and Nieuwenhuijsen et al., (2007). Their studies aimed to investigate on the level of air pollution, chemical composition and respirable particulates that the commuters are exposed while traveling on public transportation and the potential of affecting the environment (Chan et al., 2002; Nieuwenhuijsen et al., 2007). Their findings have indicated that non-air-conditioned and tram has the highest level of exposure. The dust found in the railway is considered to be even more toxic (due to high iron content) compared to ambient airborne particulates. These past studies have shown certain gaps. Firstly, most of the researches were conducted in the context of European country (e.g. France, Spain, Germany, Italy and Austria). The focus mainly is on high-speed rail, 
express rail, and electric rail with little known of heritage rail. Besides that, past studies seem to emphasis mainly on the customers' behavior towards heritage rail tourism. These studies have overlooked the importance of strategies, policies and regulations governing the sustainability of the railway industry in particular to heritage railway.

\section{METHOD}

\section{Research Approach}

In order to measure the level of sustainability of heritage rails in Taiwan, factual information, thoughts, views, and preferences by the rail operators as well as users are required to be investigated. Therefore, qualitative research is used in this research, which research was carried out in the natural setting and open-ended questions are asked based on the interviewee's experience, perception and meanings towards the issues (Hammarberg, et al., 2016). Other than that, case study approach was used to obtain a comprehensive understanding of a complicated phenomenon within its real-life context (Yin, 2012). The deteriorating heritage rails in Taiwan requires an in-depth understanding on its competitiveness as compared to other competitors such as HSR in terms of demand and costing. The data was collected through a variety of methods, inclusive of interviews, observations, and review of documents.

\section{Measures}

In this study, the adoption of Porter's Diamond Model enables the research to set directions of assessment in evaluating the challenges which Taiwan heritage rails' are facing. Porter's Diamond Model is commonly used as of national competitiveness in production of a product or service (Porter, 1990). However, it was also used as a measure of business sustainability in the field of tourism studies (e.g. Hawkins, 2004; Cunha \& Cunha, 2005; Hong, 2009). There are 4 elements in the Porter's Diamond Model, which are factor conditions, home demand conditions, related and supporting industries and firm strategy, structure and rivalry. Factor conditions refer to the local country's production factors such as manpower, natural resources, capital resources and infrastructure that enables a specific industry to create a product or service within the country or region (Ozgen, 2011). In view of this study, manpower, availability of spare parts and financial support are particularly important for the determination of the sustainability of a heritage railway industry (Zhang \& London, 2013). Next element is the home demand conditions, which refers to the local tourist demand towards the heritage rail services (Ozgen, 2011). The domestic demand of the rail tourism industry can be one important aspects of sustainable tourism (Johnson, et al., 2011). When there is a high domestic demand, it will induce the industry to innovate and produce more advanced products or services in order to strive within the industry (Zhang \& London, 2013).

The third element of Porter's Diamond Model is the related and supporting industries, which are the existence of the competitive supplying and supporting industries (Ozgen, 2011). The support of the other industries towards heritage rail tourism enables the building of network across other industries, such as hotels, travel agencies, and event companies. When the heritage rail tourism gets strong support from other industries, it would lead them to being more sustainable in terms of resources, costs, and technological transfer. Lastly, the firm strategy, structure and rivalry refers to the strategies and structures used by the heritage rail tourism operators that would influence the sustainability of its operation and to be resistant to the intensity of competition (Zhang \& London, 2013). Strategies and structures of a heritage rail operation such as the ability to react to changing environment can be one of the main source of sustainability. The ability of the heritage rail operators to come out with policies, strategies and structures that are able to tackle everchanging conditions and environment in the tourism industry is crucial (Ozgen, 2011). 


\section{Sampling Plan}

The tourism bureau of Taiwan is promoting seven heritage railways (Neiwan Line, Western Line, Jiji Line, Alishan Forest Line, Pingxi Line, Eastern Line, South Line). However, this research will only focus on Alishan Forest Railway because of its popularity and it is the only heritage railway that is highly promoted by the local government (Taiwan Railways Administration, 2016). Collection of data like interviews and observation will be done throughout the visitation to Alishan Forest Railway Administration as well as railway line leading to Alishan namely the Main Line, Zhushan Line, Mianyue Line and Shuishan Line (Taiwan Railways Administration, 2016).

Shuishan Line which is previously known as Dongpu Line has been reconstructed by the Forestry Bureau in the year of 2003, however it hasn't started its operation after the restoration, therefore it was excluded from the study. Other than that, the Taiwan Forestry Bureau was also interviewed to explore the obstacles of their operation pertaining to rail tourism development. The development of heritage rail tourism in Taiwan believed to be started at Alishan railways in the year 2008 after it has been abandoned since the 1980's after Alishan Highway was built to replace railways. On 1 July 2018, the railway was taken over by the newly established Alishan Forest Railway and Cultural Heritage Office of the Taiwan Forestry Bureau (Focustaiwan, 2018).

Table 1. Measures and data Collection Plan

\begin{tabular}{|l|l|l|}
\hline \multicolumn{1}{|c|}{ Areas } & \multicolumn{1}{|c|}{ Indicators } & \multicolumn{1}{c|}{ Data collection } \\
\hline $\begin{array}{l}\text { Factor } \\
\text { conditions }\end{array}$ & $\begin{array}{l}\text { The popularity of heritage rail among } \\
\text { the locals and tourists. } \\
\text { The effort of TRA in promoting } \\
\text { heritage rail. } \\
\text { The significance of advanced technology } \\
\text { and the capacity of heritage rail. } \\
\text { The cost incurred for maintenance. }\end{array}$ & $\begin{array}{l}\text { Onsite observation at the railway station } \\
\text { Interview with TRA and Taiwan Forestry } \\
\text { Bureau. } \\
\text { Visual materials such as photographs and } \\
\text { videotape the evidence of TRA in } \\
\text { promoting heritage rail. }\end{array}$ \\
\hline $\begin{array}{l}\text { Demand } \\
\text { conditions }\end{array}$ & $\begin{array}{l}\text { The demanding nature of the } \\
\text { consumers/government/regulators } \\
\text { towards the heritage rail. }\end{array}$ & $\begin{array}{l}\text { Interview with the Alishan Forest } \\
\text { Railway Administration and TRA with } \\
\text { regards to demand and supply. } \\
\text { Review of tourists statistic from the } \\
\text { Taiwan Railways Annual Report. }\end{array}$ \\
\hline $\begin{array}{l}\text { Related and } \\
\text { supporting } \\
\text { industries }\end{array}$ & $\begin{array}{l}\text { The role of travel agencies, } \\
\text { accommodation and TRA in } \\
\text { promoting and supporting the } \\
\text { heritage rail tourism. }\end{array}$ & $\begin{array}{l}\text { Review on the travel itinerary from the } \\
\text { travel agents and the promotion packages } \\
\text { introduced by TRA. } \\
\text { Inquiry audit on hotels located near by } \\
\text { the Alishan Railway Station. }\end{array}$ \\
\hline $\begin{array}{l}\text { Firm } \\
\text { Strategy, } \\
\text { structure \& } \\
\text { rivalry }\end{array}$ & $\begin{array}{l}\text { The support from non-profit } \\
\text { organization. } \\
\text { The competition between heritage rail } \\
\text { and HSR. }\end{array}$ & $\begin{array}{l}\text { Experiential audit on the online and } \\
\text { onsite purchasing ticket system at the } \\
\text { railway station. } \\
\text { Interview the TRA management on the } \\
\text { strategic planning of the heritage rail. } \\
\text { Review of Taiwan Railways Annual } \\
\text { Reports and Taiwan High Speed Rail } \\
\text { Annual Reports on current performance } \\
\text { and future development. }\end{array}$ \\
\hline
\end{tabular}

\section{Data Trustworthiness}

Triangulation was the approach used in this study to ensure that the data collected and the interpretation of the data to be valid and trustworthy. Triangulation is the combination of two or more data sources, researchers, methodological approaches, 
theoretical perspectives, and analytical practices within the same study (Thurmond, 2001). The four types of triangulation that promote the validity and credibility of qualitative research are methods triangulation, triangulation of sources, analyst triangulation, and theory triangulation (Patton, 1999). Methods triangulation refers to viewing the same phenomena, event, or research questions, from more than single source of material (Golafshani, 2003). For example, the sources of information are observation, interview, recording, secondary data such as journals, newspaper, and books.

The particulars coming from diverse point of view can be adopted to verify, elaborate, and elucidate the research questions. It helps in restricting methodological and personal biases, as well as improving the study's generalizability (Decrop, 1999). Triangulation of sources indicates comparing the consistency of information obtained from different sources through the same method (Patton, 1999). For instance, this can be done by interviewing variety of sources such as the tour agency operator, person in charge of heritage rail ticketing counter, and TRA officer. Generally, a set of 6 semi-structured interview questions were administered to all different respondents covering areas of concerns, challenges, reasoning, justifications and illustrations of their thoughts pertaining to the current and future aspects of the heritage railways tourism in Taiwan.

In addition, analyst triangulation was employed in this study by having multiple analysts to construe the same data collected in order to prevent personal prejudice during interpretation of data (Hussein, 2015). For example, 3 peer researchers have interpreted the data collected from interview session together to avoid potential bias, and to enhance the reliability of data. They were asked to interpret the their respective understanding before joint discussion on initial coding and subsequently joint deliberation on axial and thematic coding. Theory triangulation denotes the researchers approach the data obtained with various concepts and theories in order to have a comprehensive understanding about the data (Reeves, et al., 2008). For instance, according to stakeholder theory, a strategic and direct objective that explains the mission will help the administrations such as TRA to avoid managerial conflict, confusion, inefficiency, as well as to be more competitive in the industry (Jensen, 2001). The detail of the interviewees is stated in Table 2.

Table 2. List of respondents and brief description

Respondents

Brief description

\begin{tabular}{|c|l|}
\hline $\begin{array}{c}\text { Expert } \\
\text { A }\end{array}$ & $\begin{array}{l}\text { Senior administrator, Alishan Forest Railway Branch. More than 20 years of } \\
\text { operational experience and policies development pertaining to Alishan Forestry. }\end{array}$ \\
\hline $\begin{array}{c}\text { Expert } \\
\text { B }\end{array}$ & $\begin{array}{l}\text { Technical Specialist Recreation Division, Forestry Bureau. 15 years of experience in } \\
\text { dealing with maintenance and up keeping of heritage rail stations. }\end{array}$ \\
\hline $\begin{array}{c}\text { Expert } \\
\text { C }\end{array}$ & $\begin{array}{l}\text { Administrative Office Secretary, Taiwan Railway Administration. 8 years of experience } \\
\text { administrating issues pertaining to special projects and development of overall railway } \\
\text { system in Taiwan. }\end{array}$ \\
\hline $\begin{array}{c}\text { Expert } \\
\text { D }\end{array}$ & $\begin{array}{l}\text { Conservation and Recreation Division, Facilities Management Section, Section Chief, } \\
\text { Forestry Bureau. 12 years of experience in overseeing matters pertaining to } \\
\text { conservation practices involving Alishan Forestry. }\end{array}$ \\
\hline $\begin{array}{c}\text { Expert } \\
\text { E }\end{array}$ & $\begin{array}{l}\text { Tour guide. More than 14 years of experience in bringing tours related to cultural and } \\
\text { heritage activities within Taiwan. }\end{array}$ \\
\hline $\begin{array}{c}\text { Expert } \\
\text { F }\end{array}$ & $\begin{array}{l}\text { Senior administrator, Tourism Bureau of Kaohsiung City Government. More than 20 years } \\
\text { of experience in local tourism promotional activities, development and policy making. }\end{array}$ \\
\hline
\end{tabular}

\section{Data Analysis}

Data analysis is the process of interpretation and analysis of the data collected (Creswell, 1994). Content analysis is used throughout the analysis of data, whereby it is 
a method used by researchers to analyze data and make valid and replicable judgement through interpretation and text data coding (Hsieh \& Shannon, 2005).

\section{FINDINGS}

\section{Popularity and Promotional efforts}

The heritage rail has remained its popularity mainly due to routes leading to Alishan station. Other than that, the partnerships between Taiwan's iconic Alishan Forest Railway and Swiss railway operator Matterhorn Gotthard Bahn (MGB), along with its subsidiary Gornergrat Bahn are expected to induce product development, promote tourism in Asia and Europe, and increase the popularity of heritage railway (TaiwanToday, 2016).

Appendix 1: "Yes, the demand for the main line is very high but the supply is very low and the supply cannot meet the high demand." (Expert A)

This situation indicates that the popularity of heritage rail would remain strong due to continual effort shown in improving the rail related facilities. Product development strategy is believed to be an important source of competitive advantage. Product development that involves innovation, or modification is a necessary process for success and survival (Brown \& Eisenhardt , 1995). Other than that, the observation results and email response seem to suggest that TRA did show some degree of commitment in promoting heritage rail. Furthermore, the interview session had revealed that Forest Bureau of Taiwan (FBT) also helps in promoting heritage rail through educating visitors by distributing reading materials pertaining to the heritage railways (Appendix 2). This was supported by evidences from online audit and experiential audit, as the travel guide center, hotel in Chiayi, as well as the travel agency have assisted in promoting the heritage rail through creating and upselling tour packages in specific to heritage railways.

Appendix 2: "In order to further promote the railways, we distribute the reading materials to the people so that they can have a comprehensive understanding about heritage railway and learn to appreciate the heritage elements. As we realized people only know Alishan as a forest railway but people do not know the specialties and the heritage values and thus, we will conduct forum hoping people will have better understanding about forest railway." (Expert D)

Appendix 7: "We will have more package with travel agency to attract more foreigners to take our trains." (Expert C)

\section{Financial and non-financial support}

Based on interview session with FBT, the current profit gained by heritage railway is not sufficient to offset the high maintenance cost. However, the authorities had utilized other sources of income to support the operation of Alishan forest railway (Appendix 2). This statement is agreed by email responses from TRA (Appendix 7). Besides, it is supported by an online news stated that although high cost will be incurred in order to maintain the heritage railways in Taiwan, the government is willing to support the rail tourism (Shelley, 2015).

Appendix 2: "We are currently making 1.3 million TWD annually but the maintenance cost annually is 3.5 million TWD. Thus, we increase the price hoping it will bring us at least 1.7 million TWD annually. We will use the profit from other recreation areas to cover the losses in Alishan forest railway." (Expert B)

Appendix 3: "TRA current financial resources does not sufficient to offset the maintenance cost for heritage railway. We run repayment career to support ourselves financial issue." (Expert C) 
It seems to show that the Rail Tourism in Taiwan highly depending on revenue diversification to sustain its financial performance. These may not be a critical concern as additional revenue streams enhance the firm's financial stability, and promote greater firm's longevity causing it to sustain for longer term in the industry (Carroll \& Stater, 2009). Besides that, the heritage rail is currently receiving support in terms of financial resources from FBT (Appendix 2). It was also revealed that there is an issue of manpower and material shortage such as technician, train driver, train guides, counter attendants, as well as the supplies of spare part for the heritage rail (Appendix 1).

Based on observation, the maintenance of heritage rail is not easily done, as the number of qualified technician is limited and the area seems run-down. The issue of insufficient resources such as manpower, machine, and material would raise a question of sustainability of rail tourism here in Taiwan. This argument can be supported by resource management concept, as lack of resources would hinder the formation of capabilities and hence, inhibit the realization of competitive advantage (Sirmon et al., 2008).

Appendix 1: "The service area of Zhushan station is limited due to the crowd as people have no space to sit and they can only stand. Steam locomotives are not easy to maintain because the equipment could not be found now. The production company of the equipment and device needed for the steam locomotives were closed. We could not purchase the equipment and device for the steam locomotives.” (Expert A)

Appendix 2: "As we know, the Alishan forest railway requires high cost to maintain it, and it has low profit margin as well resulting it to experience great loss. Since TRA is considered as a company and it is not willing to bear the losses, FBT will show support to forest railway through financial resources, and FBT will be the one that bear the losses." (Expert B)

\section{Condition of Demand and supply}

The effort in promoting heritage rail are supported by various parties, which includes the government and other supporting industries. As a result, there is a positive effect on the demand for heritage rail. Furthermore, the interviews between the FBT and Alishan Forest Railway Administration (AFRA) have indicated significant demand (Appendix 1, Appendix 2). Another interview with the Expert E shows that the demand during weekend is more than weekdays (Appendix 5). The findings are validated through the news announced by the Forestry Bureau when Alishan Forest Railway Awarded with ISO9001:2008 Certificate. The Alishan Mountain is the most popular tourist attraction for the local and foreign tourists, the heritage rail is known as the most attractive one (Forestry Bureau, 2014).

Appendix 1: "Generally I think during some holidays the demand will be high. It is seasonal. Every Wednesday during the flower blossom season, the demand will be higher than usual days..." (Expert A)

Appendix 2: "Yes, the demand for the main line is very high but the supply is very low and the supply cannot reach the high demand..." (Expert B)

Appendix 3: "Yes. We have increased the train trips from Alishan to Shen Mu station and Zhao Ping stations from 10 trips to 12 trips. Before this year's May, the round trip from Alishan to Shenmu and ZhaoPing were only 10. Now we have increased it to 12 . We started the first train trip earlier...” (Expert C)

Appendix 4: "FBT does not consider this strategy because the statistics received has shown positive results whereby the seats are fully occupied...” (Expert D)

Appendix 5: "For weekday, Zhao Ping Line and Shen Mu Line are the same, but there are more people during weekends." (Expert E)

The findings evidence that the demand level for heritage rail has significant effect on the competitiveness of rail tourism. Therefore, in this case, high demand enables rail tourism to be competitive. This argument is cited by $\mathrm{Ni}$ (2012) stating that demand 
enables the organization to achieve competitveness and cost effectiveness through improving the level of production and quality of the product. However, the result acquired from the interview with Alishan Forest Railway Administration (AFRA) indicated the issues pertaining to insufficient supply such as lack of trains, lack of manpower and low capacity (Appendix 1). Similarly, FBT have commented the same remark. The findings are also evidently gathered through the observations, whereby there are minimum number of employees at the railway station and there is only one counter available for the customers to purchase their ticket. Besides that, there isn't any help desk that could provide any assistance for the customer except the ticketing counter.

Appendix 1: "The demand is high even during non-holidays season. During holidays, we would not promote because the ticket is limited and if there is a lot of people, there will be not enough capacity for them. The visitors have also complained about the insufficient of the ticket amount even during non-holidays season.” (Expert A)

These result seems to suggest that the competitiveness of the Heritage Rail Tourism in Taiwan would be disadvantage from the much equipped and manned High-speed rail counter-parts. According to Gucel (2016), the main element for the organization to be competitive and allow business to grow is the availability of resources. In view of travellers comment, common complaints pertaining to the facility of the railway station are related to the cleanliness of the toilet, and the insufficiency of seating capacity in the train. (Appendix 1).

Appendix 1: “...Sometimes we also received complaints from passengers that the toilet is not clean or the train is not enough especially the Zhushan line. The service area of Zhushan station is limited due to the crowd as people have no space to sit and they can only stand." (Expert A)

\section{Strategy, Structure and Rivalry}

The observations have shown that the online ticketing system of from Chiayi Railway Station to Fengqihu Station is not clear and confusing. The online booking system of Alishan Railway Station is also difficult for the foreign tourists. According to Taiwan Railways Administration website (www.railway.gov.tw), some of the stations do not appear as an option. Other than that, from the Alishan Forest Railway Online Ticketing System website, it only shows information using Traditional Mandarin and there are no choices of language such as English or other languages given in the website.

The issue of poor online ticketing system would affect the demand of visitors towards Alishan Railway. Visitors, mainly foreigners, may feel reluctant to visit Alishan Railway due to the inefficient online ticketing system provided by TRA, leading to lower competitiveness. According to Teimouri, Yaghoubi and Kazemi (2012), high quality electronic services would lead to higher customers purchasing intention.

There is no direct competition between other railway system and heritage rail in Taiwan. However, there is an intense competition between the heritage rail, tour buses and forest trails and shuttle buses in Alishan Railway Station (Appendix 3). There is also competition between districts tourism in Taiwan (Appendix 6).

Appendix 5: "We took the bus", "They travel through bus", "We walk up here" (Expert E)

Appendix 6: "Matters related to Alishan Railway have to interview Chiayi Tourism Bureau as it is under their govern. We are actually competing with each other to attract tourists." (Expert F)

FBT had just increased the price of the heritage rail fare in Alishan station after 20 years of fixed ticket price. The fares are set based on the distance of the railway from one station to another added with a base price set by the FBT. The setting of ticket prices 
based just on the distance is deemed unreasonable because there are other aspects such as the service provided, infrastructures offered, manpower and heritage preservation efforts that sum-up a higher operating costs.

Appendix 1: "The ticketing system is simplified by the government sector which is by using the distance to determine the price set for the tickets.... we have a base distance which if the price of the ticket is below the base price, we would add the base price and the price counted by the distance together and it would determine the price of the tickets." (Expert A)

The pricing strategy used by FBT that takes neither demand nor cost into consideration while setting the price would decrease the competitiveness of Alishan Railway and eventually affects the sustainability of the heritage railway in the future. According to Navickas and Malakauskaite (2009), price could be set based on indicators which include infrastructure development, environment, technological development, human resource, social development and human tourism in order to be competitive.

\section{Related and Supporting Industries}

Through the interviews with the tour guides in Alishan National Scenic Area (ANSA), it shows that the travel agencies do not put in a lot of effort in supporting the Alishan Heritage Railway (Appendix 3). Only 30\% of the tour guides are willing to promote Heritage Rail due to the schedule, tourist demographic and price sensitivity towards the increase of ticket price. Other than that, the itinerary of many tour agencies do not promote Heritage Railway but promoting high-speed rail as main transport.

Even though some of the tour agencies do promote Alishan, but they do not suggest travelers to go on Heritage Rail. The enquiries session at the hotels near ANSA showed negative responses towards the promotion of Heritage Railway. Through the samples, none of the staff from all hotels has suggested for Heritage Rail Tour. However, on the websites of the hotels, it does suggest Alishan Heritage Railway but it was not translated into foreign languages. Even though the website of the hotel does mention about Alishan Heritage Rail, however the last update was in the year of 2005. Other than that, some hotels do not even promote anything about Alishan on their webpage. Overall, the support of promoting Heritage Railway from the Hotels nearby is very low.

\section{Rail' (Expert C) \\ Appendix 3: 'tour guides are given authorities to decide on whether to promote Heritage}

The support from the hotel especially the concierge is much needed to improve the competitiveness of heritage rail tourism in Taiwan. According Mackenzie (2013), Concierge plays an important role in promoting the destination and creates excitement for the travelers. Besides that, TRA has a plan to draw more visitors through partnerships (Appendix 3) and FBT has given financial support to Heritage Railway (Appendix 1). While AFRA (Appendix 2) invested in maintaining the operations of the Heritage Rail.

Appendix 1: 'We have to enhance the infrastructure and make it stronger. We have to invest another amount to prevent the disaster' (Expert A)

Appendix 2: "The most significant resource to maintain forest railway is financial resource. Although the maintenance cost will be extremely high, we are still willing to repair and preserve it due to the heritage and historical value. (Expert B)

Appendix 3: 'In the future, we will have more package with travel agency and High Speed Rail to attract more foreigners to take our trains.' (expert C).

\section{CONCLUSION \& IMPLICATIONS}

Despite the high popularity, financial subsidies and effective promotion effort by TRA, heritage rail tourism in Taiwan, especially in the case of Alishan Forestry Railway, is 
facing difficulties in remaining sustainable in the long-run. Without efficient firm strategy and structure, which are poor pricing strategy and online ticketing system, it will certainly hurt the sales of heritage rail in long term, causing the heritage rail to be disadvantaged in terms of competitiveness. Moreover, without any effort of improving the lack of resources, the competitiveness of heritage rail would be heavily affected which would lead to heritage rail being unsustainable in long term. Furthermore, with the lack of support by related industries such as accommodation around the heritage rail station, travel agencies and transportation agencies to promote heritage rail in Taiwan, heritage rail tourism would not be able to reach out to more visitors, especially foreigners.

Based on the findings, the heritage rail has been taking up the financial support from the government immoderately. Hence, it is recommended for government to support the heritage rail by developing a strong domestic financial system so that it provides a clearer cash flow of the profit generated and ease the financial planning for the development of heritage rail (Jaud et al., 2013). Besides, government is suggested to understand the value of heritage rail, and implement an appropriate pricing strategy so that to increase the revenue. It might also include cooperation from accounting, finance, sales, marketing teams to guarantee the effectiveness of the strategy (Lancioni, 2005). As a result, the government will have extra resources to invest into other advantageous tourism sectors, and making the Taiwan tourism to be more competitive.

The poor utilization of technology in this fast changing world would decrease the competitiveness of heritage rail, as it will inhibit the process of internal capability accumulation, and restrain the expansion of strength of rail tourism (Voudouris et al., 2012). Besides, it would also lead to the formation of consumers' poor perception towards heritage rail. Thus, it is suggested for government to introduce sophisticated technology in order to increase the convenience in purchasing tickets. For example, mobile commerce application should be utilized because it offers convenient, localization, as well as personalized services to the consumers. This technology is proved to enhance the efficiency of complex procedures and quality of services to consumers, as well as to save the operational cost in long run (Hussin et al., 2005). Consequently, the technology innovation not only increases value in knowledge-intensive processes, but also helps to attract the foreigners to purchase tickets leading to a rise in the degree of competitiveness of rail tourism (Enkel et al., 2009). The demanding nature of the customers is inevitable. Based on the findings, little support from the government have neglected the maintenance of the railway facilities. As the administration did not respond to facilities issues immediately, these negative complaints may lead to the formation of negative perception towards the Alishan Heritage Railway causing the image of the destination to be affected adversely. Hence, the tourists might not be willing to return to the destination in the future causing an issue of the sustainability of heritage rail in long run.

Therefore, it is recommended for the organization to perform service recovery immediately after the negative complaints arisen. The lack of support from the related and supporting industries has resulted in the Alishan Heritage Railway being unable to reach out to its target market effectively. Findings showed that the heritage railway is less competitive compared to its competitors who gain support from the related and supporting industries such as travel agencies. Jackson \& Murphy (2006) stated by collaborating with the related and supporting industries closely to increase the competitiveness and reach out to customers beyond the target market more effectively.

The collaboration with the related and supporting industries enable the increase of the county's economic opportunities as it creates employment opportunities as well as business opportunities for the local communities (Ashley et al., 2007). Besides that, by working together it helps to promote the historical values of the heritage rail effectively to 
attract tourists around the world. This study is limited to the focus on Alishan Forest Heritage Railway and did not include other heritage rails in Taiwan which might cause the result to be beneficial only for Alishan Heritage Railway. However, this study is able to provide considerable insights of the competitiveness of heritage rail tourism in Taiwan. Future research is suggested to research on the overall Taiwan Heritage Railway besides Alishan Forestry Railway for a wider and complete understanding.

\section{REFERENCES}

Ashley, C., De Brine, P., Lehr, A. \& Wilde, H (2007). The role of the tourism sector in expanding economic opportunity. John F. Kennedy School of Government: Harvard University, p7.

Beirão, G. \& Cabral, J. (2010). Travelling to work or just for fun? Exploring differences in perceptions and attitudes by travel modes. Proceedings of the 12th World Conference on Transport Research society. 470-493.

Brons, M., Givoni, M. \& Rietveld, P. (2009). Access to Railway Stations and Its Potential in Increasing Rail Use. Transportation Research Part A: Policy and Practice, 43(2), 136-149.

Brown, S. L. \& Eisenhardt, K. M. (1995). Product development: Past research, present findings, and future directions. Academy of management review, 20(2), 343-378.

Carroll, D. A. \& Stater, K. J. (2009). Revenue diversification in nonprofit organizations: Does it lead to financial stability? Journal of Public Administration Research and Theory, 19(4), 947-966.

Chan, L., Lau, W., Lee, S. \& Chan, C. (2002). Commuter exposure to particulate matter in public transportation modes in Hong Kong. Atmospheric environment, 36(21), 3363-3373.

Cunha, S. K. D., \& Cunha, J. C. D. (2005). Tourism cluster competitiveness and sustainability: proposal for a systemic model to measure the impact of tourism on local development. BAR-Brazilian Administration Review, 2(2), 47-62.

Cheng, Y. (2010). Exploring passenger anxiety associated with train travel. Transportation, 37(6), 875-896.

Creswell, J. (1994). Research Design: Qualitative \& Quantitative Approaches. London: Sage Publications Ltd, p89.

Decrop, A. (1999). Triangulation in qualitative tourism research. Tourism management, 20(1), 157-161.

Forestry Bureau (2014). Alishan Forest Railway Awarded with ISO9001:2008 Certificate Again.Retrieved from: http://www.forest.gov.tw/ct.asp?xItem $=69421 \&$ ctNode $=1375 \& \mathrm{mp}=204$.

Golafshani, N. (2003). Understanding Reliability and Validity in Qualitative Research. The qualitative report, 8(4), 597-606.

Hammarberg, K., Kirkman, M. \& de Lacey, S. (2016). Qualitative research methods: when to use them and how to judge them. Human Reproduction, o(0), 1 - 4 .

Hawkins, D. E. (2004). Sustainable tourism competitiveness clusters: application to World Heritage sites network development in Indonesia. Asia Pacific Journal of Tourism Research, 9(3), 293-307.

Hsieh, H. \& Shannon, S. (2005). Three Approaches to Qualitative Content Analysis. Qualitative health research, $15(9), 1277-1288$.

Hussein, A. (2015). The use of triangulation in social sciences research: Can qualitative and quantitative methods be combined? Journal of Comparative Social Work, 4(1), 1-12.

Hussin, W. H. W., Coulton, P. \& Edwards, R. (2005). Mobile ticketing system employing Trust Zone technology. In Mobile Business, 651-654.

Hwang, J. (2010, April 17). Getting on Track. Retrieved from: http://taiwaninfo.nat.gov.tw/fp.asp?xItem= $92069 \&$ CtNode $=124$.

Jackson, J. \& Murphy, P. (2006). Clusters in regional tourism an Australian case. Annals of Tourism research, 33(4), 1018-1035.

Jain, J. \& Lyons, G. (2008). The Gift of Travel Time. Journal of Transport Geography, 16(2), 81-89.

Jaud, M., Kukenova, M. \& Strieborny, M. (2013). Finance, comparative advantage, and resource allocation. Available at SSRN 1745143, 1-26.

Jensen, R. (1999). The Dream Society (How the coming shift from information to imagination will transform your business). New York: McGraw-Hill.

Jensen, M. C. (2001). Value maximization, stakeholder theory, and the corporate objective function. Journal of applied corporate finance, 14(3), 8-21.

Johnson, G., Whittington, R. \& Scholes, K. (2011). Exploring Strategy. 9th ed. Harlow: Pearson Education Limited, P134-135.

Kolosinska, M., Petrashchak, O., Kolosinskyi, I., \& Katana, A. (2018). Tourism sector in transition economy on example of Ukraine: Determinants of Competitiveness. GeoJournal of Tourism and Geosites, 21 (1), 239-252.

Lancioni, R. A. (2005). A strategic approach to industrial product pricing: The pricing plan. Industrial marketing management, 34(2), 177-183. 
Lyons, G., Holley, D. \& Jain, J. (2008). The Business of Train Travel. Mobility and Technology in the Workplace, 74-86.

Lyons, G., Jain, J. \& Holley, D. (2007). The Use of Travel Time by Rail Passengers in Great Britain. Transportation Research Part A: Policy and Practice, 41(1), 107-120.

Navickas, V. \& Malakauskaite, A. (2009). The Possibilities for the Identification and Evaluation of Tourism Sector Competitiveness Factors. Engineering Economics, 6(1), 37 - 44.

Nieuwenhuijsen, M., Gomez-Perales, J. \& Colvile, R. (2007). Levels of particulate air pollution, its elemental composition, determinants and health effects in metro systems. Atmospheric Environment, 41(37), 7995-8006.

Ni, P. (2012). The Global Urban Competitiveness Report-2011. S.L: Edward Elgar Publishing, p12.

Ozgen, E. (2011). Porter's Diamond Model and Opportunity Recognition: A Cognitive Perspective. Academy of Entrepreneurship Journal, 17(2), 61 - 76.

Patton, M. Q. (1999). Enhancing the quality and credibility of qualitative analysis. Health services research, $34(5), 1189$.

Pine, J. B., II, \& Gilmore, J. H. (1998). Welcome to the experience economy. Harvard Business Review, 76(4), 97-105.

Porter, M. E. (1990). The competitive advantage of notions. Harvard business review, 68(2), 73-93.

Reeves, S., Kuper, A. \& Hodges, B. D. (2008). Qualitative research methodologies: ethnography. Bmj, 337(3), 1020-1022.

Shelley, S. (2015, April 4). TRA Touts 10-year Plan to Overhaul Fleet. Retrieved from: http://www.taipeitimes. com/News/taiwan/archives/2015/03/30/2003614747.

Sirmon, D. G., Hitt, M. A. \& Gove, S. (2008). Resource management in dyadic competitive rivalry: The effects of resource bundling and deployment. Academy of Management Journal, 51(5), 919-935. http://www. taipeitimes. com/News/taiwan/archives/2019/02/22/2003710198.

Thurmond, V. A. (2001). The point of triangulation. Journal of nursing scholarship, 33(3), 253-258.

Tillman, J. A. (2002). Sustainability of heritage railways: An economic approach. Japan Railway and Transport Review, 32(September), 38-45.

Voudouris, I., Lioukas, S., Iatrelli, M. \& Caloghirou, Y. (2012). Effectiveness of technology investment: Impact of internal technological capability, networking and investment's strategic importance. Technovation, 32(6), 400-414.

Watts, L. (2008). The Art and Craft of Train Travel. Social and Cultural Geography, 9(6), 711-726.

Hong, W. C. (2009). Global competitiveness measurement for the tourism sector. Current Issues in Tourism, 12(2), 105-132.

Yin, R. K. (2012). A (Very) Brief Refresher on the Case Study Method. In: R. K. Yin, ed. Applications of Case Study Research. Thousand Oaks: SAGE Publications, 3 - 19.

Zhang, P. \& London, K. (2013). Towards an internationalized sustainable industrial competitiveness model. Competitiveness Review: An International Business Journal, 23(2), 95 - 113.

*** Ceicdata (2018). View Taiwan's Number of Tourist. Retrieved from: https://www.ceicdata.com/en/taiwan/ number-of-tourists-by-tourist-attractions/number-of-tourist-ns-alishan-ns.

*** Focustaiwan (2018, June 23). Forestry Bureau to take over operation of Alishan railway. Retrieved from: http://focustaiwan.tw/news/asoc/201806230014.aspx .

*** Taiwan Tourism Bureau (2015, April 5). Rail Tour. Retrieved from: http://eng.taiwan.net.tw/m1.aspx? $\mathrm{sNo}=0002039$.

*** TaiwanToday (2016, June 13). Taiwan, Switzerland ink railway collaboration pacts. Retrieved from: http://www.centralamericaproduct.org/en/news_content.php?sn=12736.

*** Taipeitimes (2019, February 22). TRA unveils new tourist train service. Retrieved from:

*** Tour Guide (2016, May 15). Personal Interview.

*** Tourism Bureau, R. o. C. (2015, April 17). Rail Tour. Retrieved from: http://eng.taiwan.net.tw/m1.aspx?sNo $=0002039$.

Submitted:

23.07.2019
Revised:

14.10.2019
Accepted and published online 15.10.2019 